\title{
Impact of Green Human Resource Practices on Mosul University's Green Core Capabilities
}

\author{
$1^{\text {st }}$ Fatima J. Habeeb, $2^{\text {nd }}$ Ahmed Rakan Mohammad Altyar, $3^{\text {rd }}$ Baser Khalf Khazeal, \\ $4^{\text {th }}$ Lamyaa Mohammad Jasem \\ \{Fatimajh2@gmail.com ${ }^{1}$, ahm.rakan@gmail.com ${ }^{2}$, baserbbbb@gmail.com ${ }^{3}$ \}
}

Technical College of Management Mosul, Northern Technical University ${ }^{1}$, Presidency University, Northern Technical University ${ }^{2}$, Technical Institute Hawija, Northern Technical University ${ }^{3}$

\begin{abstract}
The research aims to study the relationship between the green human resource practices and green core capabilities of Mosul University. Human resource management is taking a modern direction towards green practices, which are the main source of highly skilled workers for an organization and who provide outstanding performance when it comes to the protection of the environment. A questionnaire with a three-dimensional Likert scale was used to collect data for the research. The questionnaires were distributed to a sample of 36 employees of Mosul University. SPSS was used to analyse the data for the study. The results showed that there is a significant correlation between green human resource practices and green core capabilities. The highest impact of green human resource practices in enhancing green core capabilities comes from the practice of green recruitment in the organization.
\end{abstract}

Keywords: GHRM, GCC, GHRP.

\section{Introduction:}

Nowadays, a large number of organizations appear to be practising green human resource management (GHRM) in the global context. These organizations, which are exploring and synthesizing those green practices in human resource management that should be practised by organizations and others, will contribute significantly, both academically and practically, to the area of human resource management by strengthening its green core capabilities (GCC). A search was conducted of organizational studies after the 1990s to find something on GHRM systems. It was generally observed that many of the previous studies focused on the functions of human resource management (such as recruitment, training, development, performance appraisal and rewards management), and their integration with environmental management by converting regular staff into the environmental staff to meet the environmental objectives of the organization. Thus, a significant contribution was made to the promotion of GCC. The contribution of this research was to broaden the scope and depth of GHRM in promoting GCC in the respondents' organization. Today, organizations are seeking those elements and components that will help them to achieve GCC, and promote and activate those activities and processes through which GCC can be built and strengthened. Human resource management is an important element for achieving this through the integration of environmental management and human resource management. The growing interest in the global environment and the development of international environmental management standards have led to the need for 
organizations in general, and the respondents' organization in particular, to adopt green practices to enhance their green core capabilities. Such concerns have made the respondents' organization more aware today of the increasing importance of the environment, $F$ thereby requiring it to integrate environmental management with human resource management. This research emphasized the need for environmental management to be integrated with human resource management, and to implement such practices, which are directly or indirectly linked to the environment. From these concepts, researchers are beginning to assume that GHRP will play an important role in promoting GCC. The identification of the precise parameters of the problem will help to answer the following questions:

1. What is the level of application of GHRP in the respondents' organization?

2. What is the level of GCC in the respondents' organization?

3. What is the nature of the relationship between GHRM and GCC in the respondents' organization?

4. Does GHRM contribute to the promotion of GCC in the respondents' organization?

Therefore, the research hypotheses were:

There is a significant correlation between GHRP and GCC in the respondents' organization.

There is a significant impact of GHRP on GCC in the respondents' organization.

\section{Theoretical Side:}

In order to learn about GHRM and GCC, the most relevant topics will be addressed in the following paragraphs:

2.1 Green Human Resource Management 


\subsubsection{Green Human Resource Management Concept:}

The first International Conference on the Human Environment was held in Stockholm (United Nations) in June 1972, in which the defense and improvement of the human environment for present and future generations were proclaimed. Given the importance of developing the economic environment and to reduce the gap, management scientists around the world have been analysing various management practices that enable organizations to easily accomplish the objectives of a GHRM, as these have a significant impact on the environmental competitiveness of organizations [1]. The Climate Change Conference held in Canada in 1988 also raised awareness of environmental responsibility [2]. In the light of this, scientists have called the integration of environmental management with human resource management within an organization as GHRM, and they have identified the outstanding policies in the fields of the functional dimensions of human resource management, including recruitment, performance management, evaluation, training, development, remuneration and rewards, as the tools of a firm to align employees with the company's environmental strategy for the 'greening' of functional dimensions, as defined by [3]. GHRM practices in organizations feature activities in relation to environmental protection and the preservation of an ecological balance [4] to show that the GHRM is working to support social responsibility, regardless of the sacrifice of profit, through the practise of environmentally friendly methods to reduce environmental pollution and corruption in organizations [5]. The achievement of a GHRM fully depends on the commitment of employees, which is important for achieving the organization's green goals [6]. GHRM plays an important role in acquiring the skills and experience of employees in conserving natural resources, contributing to the reduction of pollution and the control of waste, and to the production of environmentally friendly products [7]. The actions of a GHRM system involve the undertaking of environmentally friendly human resource initiatives, which will lead to increased efficiency, lower costs and improved staff participation and retention [8]. Human resource experts are working to empower organizations to conduct green businesses in different ways, such as by encouraging employees to turn off the lights and computers when they are not in use, while keeping their use to a minimum during certain hours of the year [9]. An environmentally friendly GHRM will work to use resources in such a way as to increase efficiency, reduce damage, improve working conditions as well as the employee's own life, lower costs, and improve staff performance and retention, which in turn will contribute to a flexible work schedule, recycling, remote conferencing, remote work, and online training [10].

\subsubsection{The Importance of Green Human Resource Management (GHRM):}


Employees gain many advantages by activating the application of GHRM, which includes changing the maintenance rate in the delivery of work, developing the performance of employees, making changes to the profitability, making proper use of assets, and reducing practices that cause workplace damage [11]. GHRM can develop a desire and commitment among employees to apply GHRP in order to contribute to their organization, as their ideas and efforts will lead to increased efficiency, sustainable use of resources, reduced wastage, improved career behaviour, and improved staff performance and retention [12]. GHRM works towards increasing the participation of employees in the process of environmental innovations, reducing environmental waste, developing products by increasing the efficiency of the process and reducing costs [13]. [14] identified the advantages of GHRM as a healthy work environment, increased staff morale, reduced work environment costs, environmental balance in the work environment, and flexibility in the performance of operations.

\subsubsection{Green Human Resource Management Practices (GHRMP):}

GHRP are the programs, processes and management of GHRM techniques that are implemented in organizations in order to reduce the negative impact and improve the positive impact of companies on the environment [3]. Also, GHRMP covers job analysis, recruitment, performance appraisal, micromanagement, and contributions to environmental sustainability [7]. HRM practices have been identified as training, development, performance evaluation, recruitment, selection and quality of work-life programs [2]. GHRMP includes recruitment, training, compensation and development of human capital [8]. A GHRMP scale was developed to include green recruitment, green training, green performance assessment, participation, green performance management, and compensation systems, while a GHRM encompasses five items, namely, "environmental training, investing in people, improving work-life balance and familyfriendly work, and improving health, staff safety, and staff participation in decision-making processes" [15]. GHRMP involves all the traditional human resource practices of "recruitment, selection, performance appraisal, training, and rewards" [16]. The highly developed and welldesigned practices of GHRM are likely to be a source of competitive advantage as they meet environmental standards [2].

\subsubsection{Green Recruitment:}


This includes the use of paperless appointment procedures, which, in turn, reduce the impact on the environment. Employment offers are made online for free, in the light of which, appointment forms are presented and online or telephone interviews are conducted to reduce the use of paper for such appointments. These practices reduce the rate of environmental degradation and help to improve environmental management systems through the clarity and values of an environmental culture [10]. The recruitment process is the first step towards the building of a high-quality workforce [2]. Organizations work within the overall framework of their own environmental policies, and when these environmental policies are translated and worked out, they need environmental-oriented staff, thereby, resulting in two options, the first of which is to focus on green employment, and the other is to provide the necessary awareness for environmental protection and education. The first option is more cost-effective than the second when it comes to training and staff development. "The research for best practices for green employment is important for organizations, and in the green recruitment process, some organizations integrate environmental policies and strategies with a special employment policy, where the environmental performance and reputation of the organization have been judged as a criterion for decision-making when applying for vacant posts by the staff. The Institute of Personnel and Development believes that when a staff member becomes green, he or she will improve the brand of the organization, as it is a good way to attract staff who have an environmental orientation [3]. Google uses the green recruitment method as most talented people are thought to be attracted to organizations that use a GHRM to perform their functions [11].

\subsubsection{Green Training:}

Technical development has led to the need to develop skills in the field of green techniques, and the use of these in the organization is characterized by uncertain knowledge as they involve complex dynamics. When practised, GHRM has the ability to develop knowledge strategically through the training process. Training and development practices are employed to help employees acquire the knowledge and efficiencies needed to perform work activities [2]. Training must be available to staff to educate them about energy use and waste reduction and to promote environmental awareness within the organization [8]. Green training trains staff and develops their methods of operation in order to reduce waste, optimize the use of resources, conserve energy and reduce the causes of environmental degradation, and it provides an opportunity for employees to contribute to the solving of environmental problems [10]. Training is essential for staff to understand the importance of the organization, innovation and performance upon separation [2].

\subsubsection{Green Performance Assessment:}


Measuring the employee's green performance is one of the core functions of GHRM. Without this action, no organization can maintain and ensure long-term environmental performance. The measurement criteria for green performance must conform to the environmental performance standards of the organization [3]. The role of managers in achieving green results is evaluated, as green standards are codified and integrated with successful environmental performance policies. Penalties are also established for non-compliance with environmental objectives [17].

2.1.3.4 Green Rewards:

Through green rewards, employees are given material and moral rewards for their contribution to the achievement of environmental objectives. This can stimulate and increase employee commitment to be more environmentally responsible, and thus, help to improve environmental performance [18]. If employees practice green environment-oriented tasks such as recycling, they will receive the reward for doing business [19]. [20] studied 16 organizations in 5 countries that offered rewards to their employees for their green environmental performance, and the results showed that these organizations were more inclined to apply green practices [10].

\subsection{Green Core Capabilities (GCC)}

\subsubsection{Green Core Capabilities (GCC) Concept:}

The concept of core capabilities was first proposed in 1990. GCC represents a range of individual skills that lead units and individuals in an organization to perform efficiently and effectively and to be geared towards satisfying customers and reducing the impact of competitors [21]. When applied within the organization, core capabilities are important as the minimum requirement for a set of features, such as knowledge, skills and applied attitudes that enable the employee to perform a set of tasks at an appropriate standard of efficiency and effectiveness [22]. The term 'core capabilities' refers to the ability to develop skills, knowledge, intrinsic advantages or employee attributes, and to integrate them into the application of a theory called the theory of intrinsic capacity [23]. A green core capability is the ability to learn collectively within the organization and is a distinctive organizational capability within the environmental management to apply green innovations. The environmental competitiveness of a company is derived from the GCC (tangible results of the green capability nucleus) [24]. The core capabilities of the staff within an organization must be identified through an assessment and examination of the efficiency, capabilities and functions of the organization during the process of determining the core capabilities [25]. Core capabilities reflect the collective learning of an organization and involve the coordination of diverse productive and service skills, and the integration of multiple technological streams. These include communication, participation, and a deep commitment to work across organizational boundaries such as by improving the multifunctional teams within the organization to address and overcome borders [26]. GCC is linked to working in a sustainable manner and with environmental awareness. They are characterized by a range of technical and cognitive skills, values and attitudes that must be possessed by employees to support and develop social and economic outcomes, as well as a sustainable environment in the business, industry and society [27]. Core capabilities are the key to competitiveness, and represent a range of work disciplines and the economic use of human skills. Therefore, they are a critical success factor for efficient organizations [28]. The four dimensions of core capabilities, according to [29] are self-understanding and corresponding, understanding the complexities of organizational life, building bridges of bonding through relationships, and engaging in best leadership practices. GCC can be given a procedural definition for research purposes as: A set of rare characteristics possessed by the human resources of an organization that are to be developed and maintained as long as possible for possible adoption for the environmental benefit of the organization, its staff and the society. 


\subsubsection{Importance of Core Capabilities (CC):}

According to [24], core capabilities fulfill three requirements, namely, provide access to meet a wide range of environmental market needs, make benefits available to suppliers as environmental contributions, and make it difficult to imitate the core capabilities of competitors. Core capabilities enable capacities to be translated into employment opportunities to benefit from knowledge and skills through which environmental sustainability can be implemented [30].

[21] listed the variables of core capabilities as: the selection of raw materials by the organization for the production of products and the delivery of services with the least contamination; the selection of the lowest level of energy by an organization when carrying out operations; and the use of the smallest amount of raw materials by an organization, with the products of the organization being easy to use and convertible into recycled products. Changes in the world require employees to use a set of core capabilities that are specific to their jobs [27]. Core capabilities are the skills that help an organization to identify and select the most important workers and to prepare training and development plans that are appropriate for their future environmental needs. Over the years, through an intense humanitarian effort, core capabilities are benefitting from expertise and investment in research and development, as well as in infrastructure. Organizations are working to create capabilities, which are difficult to replicate, for implementation, at least, in the short term. Core capabilities also work to help customer services by offering the best products in the shortest delivery time [31]. The organization also needs strategic flexibility to change internally and externally in order to take advantage of the vital aspects of the sustainability of core values, cultures, brands and strategic locations [32]. This flexibility has a positive impact on the adoption of green management practices as well as organizational support, and is a dynamic capability that enables organizations to effectively and quickly reconfigure and reallocate resources and capacities according to environmental changes [33]. The core capacity approach requires a continuous commitment to the development and pursuit of a long-term strategy [28] that will help to identify competitive priorities in critical functional areas within the organization [25]. In today's world, where core capabilities emerge in the midst of intense competition, their implementation has led to the creation of a strategy called the Blue Ocean Strategy. This core capability-based strategy is part of the overall strategy that is the concern of organizations. It integrates technology management (values and culture) to create a set of capabilities that disclose the highest values to customers and thus, support the service strategy [31].

\subsection{Conceptual Model:}

An attempt was made, through the hypothetical research scheme, to clarify the correlation and the effect between independent research variables the GHRP through the adoption of GCC, as shown in Figure 1.

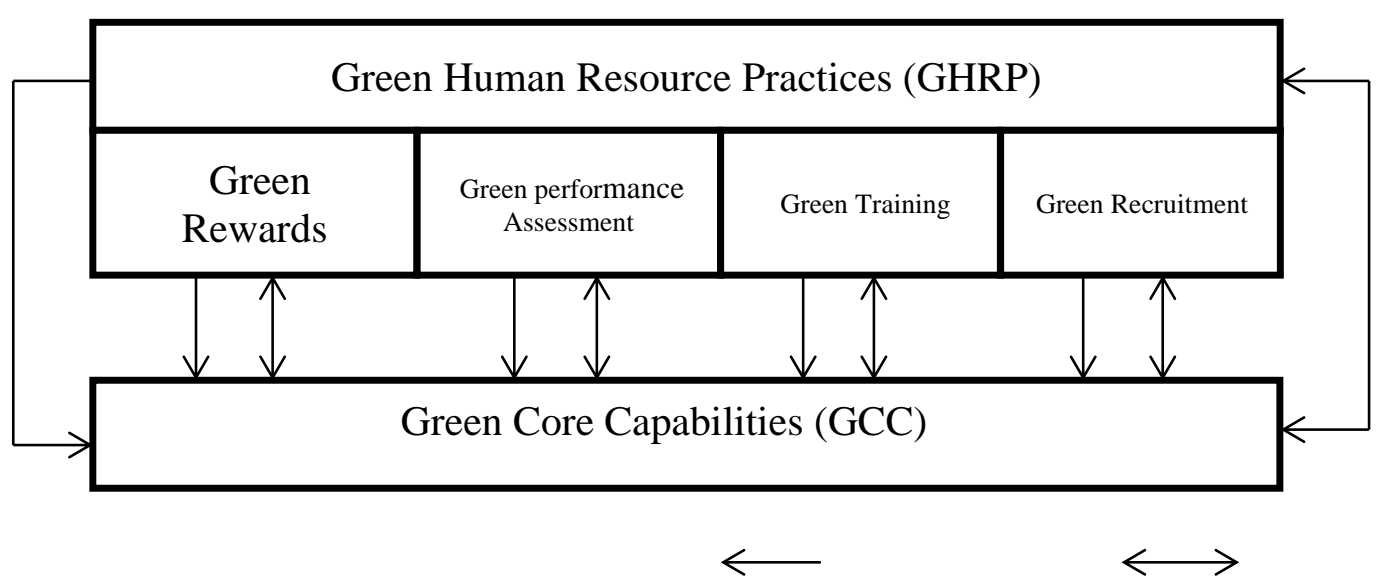


Figure .1. Conceptual Model

\section{Research Methodology:}

The research employed a descriptive-analytical approach to testing its hypotheses by examining the relationship between the independent and dependent variables, and by collecting the relevant data on the human resource management of the University of Mosul. The University of Mosul is one of the largest educational and research centres in the Middle East, and is the secondlargest university in Iraq, with 23 faculties and 4281 teaching staff. The research was based on a sample comprised of 40 directors of departments, units and divisions of the University of Mosul, of which there were 75 employees. Questionnaires were distributed to the participants and 36 were retrieved for a valid analysis.

The completion of the research required a range of research tools to gather information for the purpose of theoretical rooting, as well as to collect the field data for analysis and processing in order to validate the hypotheses and achieve the research objectives. The questionnaire was prepared and then tested by arbitrators specializing in administrative sciences. The research adopted and relied on previous studies to determine its indicators and to employ them in accordance with the research variables and the process of correlation between them [2]; [16]; [8] pertaining to GHRM practices, and to adapt the GCC indicators [24]; [27] to the current research.

\section{Result and Analysis:}

This section presents a description and analysis of the nature of the main dimensions of the research, namely, GHRM and its impact on GCC, which contributed to the construction of the research model and its hypotheses, and the interpretation of its parameters using a set of statistical methods.

1. Views of respondents on green human resource practices in their organization

In answer to the first question, "What is the level of application of GHRM in the respondents' organization?", the results showed that there was an acceptable ratio of agreement, as indicated by the proportions of the total agreement of the dimensions, noting that the highest middle of the green training came by a percentage agreement of $55 \%$, mean of 2.462 , and standard deviation of 0.712 compared to the other dimensions, which were higher than the hypothetical medium (2). Among the most important indicators that promoted the highest percentage of positive agreement for the green employment dimension were: The indicator (X2) by percentage agreement of $53 \%$, mean of 2.333, and standard deviation of 0.793 ; and indicator (x8) for the green training dimension by percentage agreement of $64 \%$, mean of 2.597 and standard deviation of 0.696 ; indicator (X7) for the dimension of the green performance assessment by agreement ratio of $72 \%$, mean of 2.667 and standard deviation of 0.585 ; indicator (X10) for the green training dimension by percentage agreement of $44 \%$, mean of 2.305 and standard deviation of 0.709 . 
Table 1. Positions of the respondents for the green human resource practices

\begin{tabular}{|c|c|c|c|c|c|}
\hline & No. & Indexes & $\begin{array}{l}\text { Agreement } \\
\text { Percentage }\end{array}$ & Mean & $\begin{array}{l}\text { Standard } \\
\text { Deviation }\end{array}$ \\
\hline \multirow{3}{*}{ 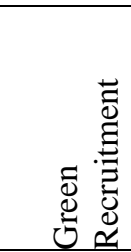 } & $\mathrm{x} 1$ & $\begin{array}{l}\text { The organization adopts environmental policies and } \\
\text { strategies when recruiting workers. }\end{array}$ & $47 \%$ & 2.222 & 0.831 \\
\hline & $\mathrm{x} 2$ & $\begin{array}{l}\text { The organization continuously advertises its } \\
\text { employees' needs through its electronic websites. }\end{array}$ & $53 \%$ & 2.333 & 0.793 \\
\hline & $\mathrm{x} 3$ & $\begin{array}{l}\text { The organization selects workers who have } \\
\text { behaviors that support environmental orientation. }\end{array}$ & $39 \%$ & 2.139 & 0.798 \\
\hline \multicolumn{3}{|c|}{ Total Index } & $46 \%$ & 2.231 & 0.807 \\
\hline \multirow{3}{*}{ 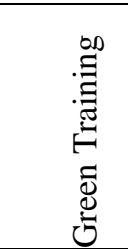 } & $\mathrm{x} 4$ & $\begin{array}{l}\text { The organization uses its own websites to } \\
\text { implement training courses for its employees. }\end{array}$ & $47 \%$ & 2.375 & 0.749 \\
\hline & $\times 5$ & $\begin{array}{l}\text { The organization announces seminars and training } \\
\text { courses on its website. }\end{array}$ & $53 \%$ & 2.416 & 0.691 \\
\hline & $x 6$ & $\begin{array}{l}\text { The organization has the necessary supplies to } \\
\text { implement the training courses electronically. }\end{array}$ & $64 \%$ & 2.597 & 0.696 \\
\hline \multicolumn{3}{|c|}{ Total Index } & $55 \%$ & 2.462 & 0.712 \\
\hline \multirow{3}{*}{ 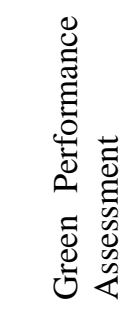 } & $\mathrm{x} 7$ & $\begin{array}{l}\text { The organization has indicators to assess the } \\
\text { performance of green workers in the annual } \\
\text { performance appraisal system. }\end{array}$ & $72 \%$ & 2.667 & 0.585 \\
\hline & $\mathrm{x} 8$ & $\begin{array}{l}\text { The organization has websites to assess employee } \\
\text { performance. }\end{array}$ & $58 \%$ & 2.583 & 0.500 \\
\hline & $\mathrm{x} 9$ & $\begin{array}{l}\text { There are procedures in the organization that } \\
\text { support the performance of green workers. }\end{array}$ & $33 \%$ & 2.111 & 0.747 \\
\hline \multicolumn{3}{|c|}{ Total Index } & $54 \%$ & 2.454 & 0.610 \\
\hline \multirow{3}{*}{ 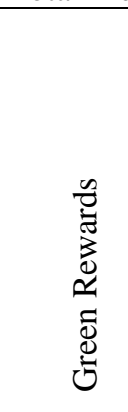 } & $\mathrm{x} 10$ & $\begin{array}{l}\text { The organization adopts a system of moral } \\
\text { incentives more broadly than material incentives to } \\
\text { enhance environmental orientation. }\end{array}$ & $44 \%$ & 2.305 & 0.709 \\
\hline & $\mathrm{x} 11$ & $\begin{array}{l}\text { The organization rewards employees with distinct } \\
\text { environmental behaviors that contribute to } \\
\text { generating green initiatives }\end{array}$ & $41 \%$ & 2.194 & 0.786 \\
\hline & $\mathrm{x} 12$ & $\begin{array}{l}\text { The organization announces on its website the } \\
\text { names of employees who are distinguished in their } \\
\text { environmental performance. }\end{array}$ & $44 \%$ & 2.278 & 0.741 \\
\hline \multicolumn{3}{|c|}{ Total Index } & $43 \%$ & 2.259 & 0.745 \\
\hline
\end{tabular}

This suggested that the respondents' organization had the potential to meet a wide range of environmental needs that were difficult for other universities to imitate, and it translated capabilities into job opportunities to leverage on knowledge and skills that can support environmental sustainability.

Testing of Hypotheses

1. Testing the correlation between GHRP and GCC: 
The third question was, "What is the nature of the relationship between GHRP and GCC in the respondents' organization?". Table 3 shows the results of the correlation between GHRP and GCC in the respondents' organization. It was noted that there was a positive correlation between GHRP and GCC in the respondents' organization, with the total index of the relationship being $(0.751 *)$ at the sub-level of the practices. It was noted that after the green employment point, the highest correlation relationship with GCC reached $(0.634 *)$, which generally indicates a good correlation between the dimensions of a research. This indicated that whenever the human resources in the respondents' organization adopted green practices by reducing the use of materials and energy in their processes and activities, they enhanced their green core capabilities. Thus, the first major hypothesis was achieved.

Table 3. Correlation between GHRP and GCC.

\begin{tabular}{|l|l|}
\hline \multicolumn{1}{|c|}{ Dependent variable } & GCC \\
Independent variable & \\
\hline Green Recruitment & $* 0.634$ \\
\hline Green Training & $* 0.531$ \\
\hline Green Performance Assessment & $* 0.498$ \\
\hline Green Rewards & $* 0.607$ \\
\hline Total Index & $* 0.751$ \\
\hline
\end{tabular}

$\mathrm{P} \leq 0.05 \mathrm{n}=36$

\section{The influencing relationship of GHRP on GCC}

The second question was, "Does the GHRP contribute to the promotion of GCC in the respondents' organization?" The second key hypothesis was developed as the results of the regression analysis in Table (4) showed that GHRP had a moral impact when combined with GCC in the respondents' organization. The calculated value (F) was 35.405, and was greater than its high attribute value of 3.91 at a morale level of 0.05 . The independent variant of the explanatory coefficient (R2) was valued at 0.51 . By following up the value (B1) of 0.751 and its calculated $(\mathrm{t})$ value of 5.950, which was greater than its attribute value of 1.684 at a morale level of 0.05 , it was indicated that GHRP had a significant impact on the GCC in the respondents' organization.

Table 4. Impact of green human resource practices GHRP on GCC

\begin{tabular}{|c|c|c|c|c|c|}
\hline $\begin{array}{c}\text { Dependent } \\
\text { Kariable }\end{array}$ & \multicolumn{2}{|c|}{ GCC } & \multirow{2}{*}{$\mathrm{R}^{2}$} & \multicolumn{2}{|c|}{$\mathrm{F}$} \\
\cline { 6 - 6 } $\begin{array}{c}\text { Independent } \\
\text { Variable }\end{array}$ & $\mathrm{B}_{0}$ & $\mathrm{~B}_{1}$ & & Calculated & Tabled \\
\hline GHRP & 0.392 & $\begin{array}{c}0.751 \\
\left(5.950^{*}\right)\end{array}$ & 0.53 & 35.405 & 3.91 \\
\hline
\end{tabular}


The impact of green human resource practices (GHRP) on the GCC can be defined in the respondents' organization, as the results of the analysis in Table 5 showed that GHRP had a moral impact on GCC, and this was the highest impact of the green recruitment practice on the GCC through the coefficient (R2) of 0.40 compared to the other green practices. This indicated that the respondents' organization followed recruitment procedures that reduced its impact on the environment by integrating its environmental policies and strategies with the recruitment process, thereby strengthening the GCC in the respondents' organization. On the basis of this, the second major hypothesis was achieved.

Table 5. Impact of green human Resource practices GHRP on CCG

\begin{tabular}{|l|c|c|c|c|c|}
\hline \multirow{2}{*}{ Dependent Variable } & \multicolumn{2}{|c|}{ GCC } & \multirow{2}{*}{$\mathrm{R}^{2}$} & \multicolumn{2}{c|}{$\mathrm{F}$} \\
\cline { 3 - 6 } Independent Variable & $\mathrm{B}_{0}$ & $\mathrm{~B}_{1}$ & & $\begin{array}{c}\text { Calcula } \\
\text { ted }\end{array}$ & Tabled \\
\hline \multicolumn{1}{|c|}{ Green Recruitment } & 1.209 & $\begin{array}{c}0.461 \\
\left(4.776^{*}\right)\end{array}$ & 0.40 & 22.81 & 3.91 \\
\hline Green Training & 1.131 & $\begin{array}{l}0.458 \\
\left(3.652^{*}\right)\end{array}$ & 0.28 & 13.33 & 3.91 \\
\hline Green Performance Assessment & 1.186 & $\begin{array}{l}0.429 \\
\left(2.531^{*}\right)\end{array}$ & 0.20 & 6.41 & 3.91 \\
\hline Green Rewards & 1.101 & $\begin{array}{l}0.503 \\
\left(4.449^{*}\right)\end{array}$ & 0.37 & 19.78 & 3.91 \\
\hline
\end{tabular}

$$
\mathrm{P} \leq 0.05 \quad \mathrm{n}=36
$$

\section{Conclusions}

The most important conclusions to be drawn from the above research were as follows

1. There are positive trends that are acceptable to the respondents' organization towards the application of green human resource management (GHRM) practices, as reflected in the achievement of its environmental objectives, and the enhancement of its core green capabilities. 2. The respondents' organization possesses GCC that have enabled it to carry out the tasks and duties entrusted to it in protecting the environment, as reflected in its success as compared to other universities.

3. The priorities of the respondents' organization with regard to GHRP are focused on green training, which contributes to the rationalization of their behaviour towards the environment.

4. The priority of the respondents' organization is to support GCC to reduce the use of energy in its operations through GHRP, which are the most valuable resources of the organization that can be continually developed and sustained towards environmental orientation.

5. The respondents' organization has achieved GCC through its environmental policies and strategies, which have been employed in its recruitment processes and procedures. 
6. The increased application of GHRP in the respondents' organization has contributed positively to the promotion of GCC. Most of the links between GHRP and GCC have been positive and morally significant.

7. The GCC have strengthened the respondents in an integrated manner from the impact of GHRP, by way of possessing most of the estimated human resources to make decisions that have positively contributed to the organization's environmental orientation, and that green employment has been more influential in the promotion of GCC.

8. The support and assistance of senior management and the provision of human resources in the respondents' organization are the foundations for the building and strengthening of GCC.

\section{References:}

1. Dmeiio, L, Manjush, H. H. \&. Meena M.: A study on the green human resource management at gateway hotel. Social Work Department, Srinivas Institute of Management Studies, Mangalore, Karnataka. International Journal of Scientific Research and Modern Education (IJSRME). pp. 843(2455 - 5630) (2016).

2. Almada, L. \& Renata, B.: Sustainable Competitive Advantage Needs Green Human Resource Practices: A Framework for Environmental Management, Revista de Administração Contemporânea. pp. 424-442 (2018).

3. Arulrajah, A. A., Opatha, H. H. D. N. P., \& Nawaratne, N. N. J.: Green human resource management practices: A review. Sri Lankan Journal of Human Resource Management, 5(1) (2015).

4. Kothiswari, L.: The Role of Green Human Resource Management Towards Employee Engagement in Organization, Idhaya College of atrs and science for women, Pondicherry. International Journal of Advance Engineering and Research Development, Vol. 5(02), pp. 2348-6406 (2018).

5. Chowdhury, S. R., N. L. S., \& Asaduzzaman, A. K. M.: Green HRM Practices as a Means of Promoting CSR: Suggestions for Garments Industry in Bangladesh. Global Journal of Management and Business Research (2017).

6. Sriram., V.P.\& Suba, M.: Impact of Green Human Resource Management (G-HRM) Practices over Organization Effectiveness. Department of Business Administration, Kalasalingam University. Tamilnadu, India. Jour of A dv Research in Dynamical \& Control Systems, 07-Special Issue (2017).

7. Uddin, M.: Practicality of Green Human Resource Management Practices: A Study on Banking Sector in Bangladesh. Department of Business Administration. University of Asia Pacific, Dhaka, Bangladesh, International Journal of Economics. Commerce and Management United Kingdom. 6, 382 (2017).

8. Deepika. R, \& Karpagam, V.: A study on green HRM practices in an organization, School of Management Studies, Vels University, Tamil Nadu, India. International Journal of Applied Research, Vol. 2(8), pp.426-429 (2016).

9. Mehta, K., \& Chugan, P. K.).: Green HRM in pursuit of environmentally sustainable business. Pursuit of Environmentally Sustainable Business. Universal Journal of Industrial and Business Management, Vol. 3(3), pp. 74-81 (2015). 
10. Bangwal, D., \& Tiwari, P.: Green HRM-A way to greening the environment. Iosr J. Bus. Manag, Vol. 17, pp. 45-53. (2015).

11. Kulshrestha, S. S. \& Shruti, S.: Green HRM:A New Trend in Enhancing Green Behaviour at Workplace, Mangalmay Institute of Management And Technology, Greater Noida., International Journal of Advanced Scientific and Technical Research (2018).

12. Peerzadah, S. A., Sabiya M. \& Nazir A. N.: Green Human Resource Management: A Review, Research Scholar, Department of Commerce, University of Kashmir, India. International Journal of Enhanced Research in Management \& Computer Applications ISSN: 2319-7471, Vol.7 (3), pp. 790 (2018).

13. Bombiak, E., \& Marciniuk-Kluska, A.: Green human resource management as a tool for the sustainable development of enterprises: Polish young company experience. Sustainability, Vol. 10(6), pp. 1739 (2018).

14. Parveen, S. M., \& Phil. M.: Green Human Resource Management (GHRM), P.G Department of Commerce, Vol. 5 (2018).

15. Ren, S., Tang, G., \& Jackson, S. E.: Green human resource management research in emergence: A review and future directions. Asia Pacific Journal of Management, Vol. 35(3), pp. 769-803 (2018).

16. Jabbour, C. J. C. \& de Sousa Jabbour, A. B. L.: Green human resource management and green supply chain management: Linking two emerging agendas. Journal of Cleaner Production, Vol. 112, pp. 1824-1833 (2016).

17. Vasa, S. R. \&. Sowdamini, T.: Green work life balance \& green HRM: A new replica for organisational triumph, Associate Professor, Department of Management Studies, Pydah College of Eng. \& Tech, Visakhapatnam, Andhra Pradesh, India, Gitam University, Visakhapatnam, Andhra Pradesh, India, International Journal of Academic Research and Development ISSN: 2455-4197, Impact Factor: RJIF 5.22, Vol. 2(4), pp. 456-461(2017).

18. Singh,A.L., \& Shikha, G.: Impact of green human resource factors on environmental performance in manufacturing companies: An empirical evidence. International Journal of Engineering and Management Sciences, 6(1), 25-30 (2015).

19. Yusoff, Y. M., Othman, N. Z., Fernando, Y., Amran, A., Surienty, L., \& Ramayah, T. : Conceptualization of green human resource management: an exploratory study from Malaysian-based multinational companies. International Journal of Business Management \& Economic Research, Vol. 6(3), pp. 1 (2015).

20. Taylor, S.R.Green management: the next competitive weapon Futures, Vol. 24 (7), pp. 669680 (1992).

21. Trott, D. S.: The Impact of Green Core Competencies on Green Image and Green Innovation-an Indian Perspective. ITM-SIA Business School, Paradigm, Vol. 17(1-2), pp. 81-87 (2016).

22. Albarqouni, L., Hoffmann, T., Straus, S., Olsen, N. R., Young, T., Ilic, D. , \& Glasziou, P.: Core competencies in evidence-based practice for health professionals: consensus statement based on a systematic review and Delphi survey. JAMA network open, Vol. 1(2), e180281-e180281 (2018).

23. Rasidah, H. , M. H. Azman Ong, N. Baba, M. A. Burhanuddin, J. Jami, H. Hassan \& Mohd, A.: Perceived Value And Destination Image Enhanced Environmental Awareness In Green Hotel Industry: The Mediating Effect Of Core Competencies, Faculty of Hotel and Tourism Management, Universiti Teknologi MARA, The Turkish Online Journal of Design, Art and Communication - Tojdac, ISSN: 2146-5193, pp.693-700 (2018). 
24. Chan, J. S.: Measuring the Green Core Competence of the Electronics Industry. Ateneo de Manila University Graduate School of Business, Published by the Ateneo de Manila University Graduate School of Business. No. 11(2010).

25. Odero., O. E.: Core competencies and choice of competitive. Strategies at equity bank limited in Kenya, a research project submitted in partial fulfillment of the requirements for the degree of master of business administration. School of business, university of Nairobi (2013).

26. Kawshala, H.: Theorizing the Concept of Core Competencies: An Integrative Model beyond Identification, Department of Commerce and Financial Management. Faculty of Commerce and Management Studies, University of Kelaniya, Sri Lanka. International Journal of Scientific and Research Publications, Vol. 7(2), pp. 2250-3153 (2017).

27. Nishimoto. T.: Regional Model ompetency Standards: Core competencies. Regional Office for Asia and the Pacific. Copyright International Labour Organization First published. ISBN (2015).

28. Uysal, G.: Core Competence: A Competitive Base for Organizational Success, Hacettepe University, Turkey, Journal of Global Strategic Management (2007).

29. Ross, D. J., \& Cozzens, J. A.: The principalship: Essential core competencies for instructional leadership and its impact on school climate. Journal of Education and training Studies, Vol. 4(9), pp.162-176 (2016).

30. Bickell, S.: Defining a profession: core competencies for sus, cem occasional paper series ta inability, college of estate management (2013).

31. Gupta, R. K.: Competencies - Concepts and relevance Area: Strategic Management. General Management Document: Sobhagya Consultancy \& Marketing Services - India, M10, No 7 (2014).

32. Sushil, S.: Strategic flexibility: The evolving paradigm of strategic management. Global Journal of Flexible Systems Management, Vol. 16(2), pp. 113-114 (2015).

33. Yang. J., Zhang. F., Jiang. X. \& Sun. W.: Strategic flexibility, green management, and firm competitiveness in an emerging economy, School of Management, Xi'an Jiaotong University (2015). 